\title{
PENTINGNYA RESTORATIVE JUSTICE DALAM KONSEP IUS CONSTITUENDUM
}

\author{
Zico Junius Fernando \\ Fakultas Hukum Universitas Bengkulu \\ Jalan WR. Supratman Kandang Limun Kota Bengkulu, Bengkulu \\ Pos-el: zjfernando@unib.ac.id.
}

\begin{abstract}
The State of Indonesia is a state of law, the affirmation of this can be seen in Article 1 paragraph (3) of the 1945 Constitution of the Republic of Indonesia. Settlement of cases through the judicial system which results in a court verdict is a law enforcement towards the slow path. This is because law enforcement through a long distance, through various levels starting from the Police, Attorney General's Office, District Court, High Court and even to the Supreme Court which ultimately has an impact on the accumulation of cases which are not small in number in the Court and not to mention other effects. For this reason, it is necessary to proceed with the steps to compile invitations concerning the rights and obligations of citizens in the context of implementing the Pancasila and the 1945 Constitution. Renewal of the Criminal Code by its authors is positioned as the foundation for building a national criminal law system. Related to the Political Law of Criminal Law Renewal in the upcoming National Criminal Law there is a concept known as the Restorative Justice concept. Restorative Justice involves restoring relations between the victim and the perpetrator. The restoration of this relationship can be based on mutual agreement between the victim and the perpetrator. The victim can convey about the loss he suffered and the perpetrator was given the opportunity to make it up, through compensation mechanisms, peace, social work, and other agreements.
\end{abstract}

Keywords: Restorative Justice; Legal Reform; RKUHP

\begin{abstract}
Abstrak: Negara Indonesia adalah negara hukum, penegasan akan hal ini dapat dilihat dalam Pasal 1 ayat (3) UndangUndang Dasar Negara Republik Indonesia Tahun 1945. Penyelesaian perkara melalui sistem peradilan yang berujung pada vonis Pengadilan merupakan suatu penegakan hukum ke arah jalur lambat. Hal ini dikarenakan penegakan hukum itu melalui jarak tempuh yang panjang, melalui berbagai tingkatan mulaidari Kepolisian, Kejaksaan, Pengadilan Negeri, Pengadilan Tinggi bahkan sampai ke Mahkamah Agung yang pada akhirnya berdampak pada penumpukan perkara yang jumlahnya tidak sedikit di Pengadilan dan belum lagi efek lainnya. Untuk itu perlu dilanjutkan langkah-langkah untuk menyusun perUndang-Undangan yang menyangkut hak dan kewajiban asasi warga negara dalam rangka mengamalkan Pancasila dan UUD Tahun 1945. Pembaruan terhadap KUHP oleh penyusunnya diposisikan sebagai peletak dasar bagi bangunan sistem hukum pidana nasional. Terkait dengan Politik Hukum Pembaharuan Hukum Pidana dalam Hukum Pidana Nasional yang akan datang ada konsep dikenal namanya konsep Restorative Justice. Restorative Justice meliputi pemulihan hubungan antara pihak korban dan pelaku. Pemulihan hubungan ini bisa didasarkan atas kesepakatan bersama antara korban dan pelaku. Pihak korban dapat menyampaikan mengenai kerugian yang dideritanya dan pelaku pun diberi kesempatan untuk menebusnya, melalui mekanisme ganti rugi, perdamaian, kerja sosial, maupun kesepakatan lainnya.
\end{abstract}

Kata Kunci : Restorative Justice; Pembaharuan Hukum; RKUHP

AL-IMARAH: Jurnal Pemerintahan dan Politik Islam 


\section{Pendahuluan}

Negara Indonesia adalah negara hukum (rechtsstaat), penegasan akan hal ini dapat dilihat dalam Pasal 1 ayat (3) UndangUndang Dasar Negara Republik Indonesia Tahun 1945. Menurut Daniel S. Lev, penegasan yuridis-konstitusional oleh para founding fathers sebagaimana di atas sangatlah tepat, karena memang secara sosiologis berbagai golongan masyarakat Indonesia juga menopang atau setuju negara hukum dengan berbagai alasan. ${ }^{1}$ Sistem perencanaan pembangunan nasional adalah satu kesatuan tata cara pembangunan untuk menghasilkan rencana-rencana pembangunan dalam jangka panjang, jangka menengah, dan jangka tahunan yang dilaksanakan oleh unsur penyelenggara negara dan masyarakat di tingkat pusat dan daerah. $^{2}$

Sistem perencanaan pembangunan nasional dalam penyelenggaraannya didasarkan atas asas umum penyelenggaraan negara, yang bertujuan untuk mendukung koordinasi antara pelaku pembangunan, menjamin terciptanya integrasi, sinkronisasi,

\footnotetext{
1 Daniel S. Lev, Hukum dan Politik di Indonesia: Keseimbangan dan Perubahan, Cetakan I, LP3ES, Jakarta, 1990, h. 386.

${ }^{2}$ Pasal 1 Ayat (3) Undang-Undang Nomor 25 Tahun 2004 Tentang Sistem Perencanaan Pembangunan Nasional.
}

dan sinergi baik antar daerah, antar ruang, antar waktu, antara fungsi pemerintah maupun antar pusat dan daerah, menjamin keterkaitan dan konsistensi antara perencanaan, penganggaran, pelaksanaan dan pengawasan, mengoptimalkan partisipasi masyarakat, dan menjamin tercapainya penggunaan sumber daya secara efisien, efektif, berkeadilan, dan berkelanjutan. ${ }^{3}$

Di era modernisasi ini banyak terjadi suatu kejahatan (delik) dikalangan masyarakat indonesia yang berujung pada jalur Pengadilan (litigasi), dimana masyarakat cenderung menggunakan jalur yang namanya Pengadilan sebagai upaya dalam menyelesaikan suatu perkara yang yang menurut mereka secara konseptual dan teoritis akan menciptakan keadilan, namun dalam kenyataan atau tataran law in action nya hal tersebut malah justru tidak mudah untuk dicapai karena sifatnya yang cenderung bersifat win lose solution, dengan kenyataan seperti ini, penyelesaian suatu perkara melalui jalur peradilan yang sifatnya hanya win lose solution pada umumnya kerap menimbulkan rasa "tidak enak atau kecewa", 
AL-IMARAH: Jurnal Pemerintahan dan Politik Islam Vol. 5, No. 2, 2020

menyimpan dendam, merasa tidak puas, merasa tidak adil bahkan lebih parah yaitu berniat ingin membalas dendam.

Rasa tidak enak atau kecewa tersebut yang tertanam kuat dibenak pihak yang kalah akan berupaya untuk mencari "keadilan" ketingkat peradilan lebih lanjut seperti Pengadilan Tinggi (PT), Mahkamah Agung (MA) bahkan sampai ke Mahkamah Konstitusi (MK). Hal tersebut sudah barang tentu menyebabkan terjadi penumpukan perkara yang mengalir melalui Pengadilan yang dapat menghambat sistem peradilan khususnya yang ada di Indonesia. Dari fenomena tersebut, benarlah apa yang dikemukakan oleh Joni Emirzon dalam bukunya berjudul Alternatif Penyelesaian Sengketa di Luar Pengadilan, bahwa hal ini pada umumnya dapat dikategorikan sebagai salah satu kelemahan bagi suatu lembaga litigasi yang tidak dapat dihindari walaupun sudah menjadi suatu ketentuan. ${ }^{4}$

Satjipto Raharjo yang menyatakan bahwa penyelesaian perkara melalui sistem peradilan yang berujung pada vonis Pengadilan merupakan suatu penegakan hukum (law enforcement) ke arah jalur

4 Joni Emirzon, Alternatif Penyelesaian Sengketa di Luar Pengadilan, Jakarta, PT. Gramedia Pustaka Utama, 2001, h. 3-5.

lambat. Hal ini dikarenakan penegakan hukum itu melalui jarak tempuh yang panjang, melalui berbagai tingkatan mulaidari Kepolisian, Kejaksaan, Pengadilan Negeri, Pengadilan Tinggi bahkan sampai ke Mahkamah Agung yang pada akhirnya berdampak pada penumpukan perkara yang jumlahnya tidak sedikit di Pengadilan. ${ }^{5}$

Untuk itu perlu dilanjutkan langkahlangkah untuk menyusun perUndangUndangan yang menyangkut hak dan kewajiban asasi warga negara dalam rangka mengamalkan Pancasila dan UndangUndang Dasar Negara Kesatuan Republik Indonesia Tahun 1945. Diharapkan seluruh warga negara Indonesia harus selalu sadar dan taat kepada hukum, sebaliknya kewajiban negara untuk menegakkan dan menjamin kepastian hukum. ${ }^{6}$

Romli Atmasasmita mengemukakan pendapatnya sebagai berikut: "Hukum Nasional (Indonesia) sebagai suatu sistem belum terbentuk secara holistik, komprehensif, ataupun belum diperkaya nilai-nilai kehidupan masyarakat adat untuk beradaptasi dengan kehidupan masyarakat maju. Usaha untuk menyatakan telah terdapat suatu sistem hukum nasional, terbukti hanya merupakan pewarisan sistem hukum pewarisan Hindia Belanda yang menganut "Civil Law System" semata-mata yang

5 Satjipto Rahardjo, Sisi-Sisi Lain dari Hukum di Indonesia, Jakarta: Kompas, 2003, h. 170.

6 Abdul Manan, Aspek-Aspek Pengubah Hukum, Kencana Prenada Media, Jakarta, 2009, h. 5. 
dipaksakan berlakunya ditengah-tengah masyarakat hukum adat. Perubahan terhadap KUHP pada masa pasca kemerdekaan Republik Indonesia dan setelah era reformasi, antara lain dilakukan dengan memasukan ketentuan mengenai pembajakan udara dan larangan ideologi marxisme-komunisme. Pembentukan sistem hukum nasional sampai saat ini masih belum selesai dan patut dipertanyakan sebelum dan setelah Indonesia memasuki era reformasi, pembentukan tersebut lebih banyak hasil harmonisasi pengaruh hukum asing atau hukum Internasional ke dalam peraturan perUndangUndangan".?

Pembaruan terhadap Kitab UndangUndang Hukum Pidana (selanjutnya disebut KUHP) oleh penyusunnya diposisikan sebagai peletak dasar bagi bangunan sistem hukum pidana nasional. Sejalan dengan itu, upaya pembaruan itu mengusung misi besar yaitu: dekolonialisasi terhadap KUHP peninggalan/warisan kolonial, demokratisasi hukum pidana, konsolidasi hukum pidana, dan adaptasi serta harmonisasi berbagai perkembangan baik secara nasional maupun internasional. Turunan dan penjabaran dari misi besar itu adalah perubahan baik secara terbatas maupun drastis paradigma hukum pidana sebagaimana termuat dalam KUHP saat ini.

7 Romli Atmasasmita, Teori Hukum Integratif: Rekonstruksi Terhadap Teori Hukum Pembangunan dan Teori Hukum Progresif, Genta Publishing, Yogyakarta, 2012, h. 60-61.
Adapun karakteristik dari sistem hukum nasional nantinya, tergantung dari politik hukum nasional Indonesia. Dengan perkataan lain, bahwa politik hukum nasional Indonesia akan menentukan karakteristik dari sistem hukum nasional Indonesia. Jadi terciptanya sistem hukum nasional yang berfilsafatkan Pancasila dan berdasarkan Undang-Undang Dasar Negara Kesatuan Republik Indonesia Tahun 1945, tergantung dari politik hukum nasional. ${ }^{8}$ Terkait dengan Politik Hukum Pembaharuan Hukum Pidana dalam Hukum Pidana Nasional yang akan datang akan ada dikenal namanya konsep Restorative Justice (Keadilan Restoratif).

Konsep Restorative Justice (Keadilan Restoratif) ini tergolong baru dalam proses penegakan hukum pidana dan juga mempertanggungjawabkan pelakunya. Secara filosofis, konsep ini menawarkan bentuk penyelesaian berbagai kasus hukum yang terjadi di luar proses peradilan pidana yang sudah ada, agar masyarakat tidak hanya tergantung pada prosedur yang ada saat ini sesuai dengan cerminan nilai-nilai Pancasila yakni "Permusyawaratan yang adil dan Beradab" guna mencapai keadilan sosial bagi

8 Otong Rosadi dan Andi Desmon, Studi Politik Hukum: Suatu Optik Ilmu Hukum, Edisi II, Thafa media, Yogyakarta, 2013, h. 45. 
AL-IMARAH: Jurnal Pemerintahan dan Politik Islam Vol. 5, No. 2, 2020

seluruh rakyat atau warga masyarakat di Republik Indonesia. Salah satu bentuk solusi yang ditawarkan adalah proses penyelesaian dalam konteks Restorative Justice (Keadilan Restoratif).

\section{Pembahasan}

\section{Pengertian Restorative Justice (Keadilan Restorasi)}

Konsep Restorative Justice sebenarnya telah muncul cukup lama, kurang lebih dari dua puluh tahun yang lalu sebagai alternatif penyelesaian perkara pidana, khususnya anak, dengan berbagai pertimbangannya. Sebagaimana dikemukakan oleh John Braithwaite bahwa, Restorative Justice sebuah arah baru antara "justice" dan "walfare model”, kemudian antara "retribution" dan "rehabilitation". 9

Di Amerika Utara, Australia, dan sebagian Eropa, keadilan restoratif sudah diterapkan pada semua tahap proses peradilan pidana konvensional yaitu tahap penyidikan dan penuntutan, tahap adjudikasi dan tahap eksekusi pemenjaraan.

Dalam perkembangan, pertumbuhan, dan penyebaran keadilan restoratif mendapat

9 John Brithwaite, Restorative Justice and Responsive Regulation, University Press, Oxford, 2002, h. 1. dukugan Perserikatan Bangsa-Bangsa (PBB). Dalam Kongres Lima Tahunan yang ke-5 di Jenewa tahun 1975, PBB mulai menaruh perhatian terhadap ganti rugi bagi korban kejahatan, sebagai alternatif bagi peradilan pidana retributif. Konsep asli praktek keadilan restoratif berasal dari praktek pemeliharaan perdamaian yang digunakan suku bangsa Maori (penduduk asli suku di Selandia Baru). Bilamana timbul konflik, praktek restoratif akan menangani pihak pelaku, korban, dan para stakeholders. ${ }^{10}$ Bahkan Jeff Christian, seorang pakar Lembaga Pemasyarakatan Internasional dari Kanada mengemukakan bahwa sesungguhnya peradilan restoratif telah dipraktekkan banyak masyarakat ribuan tahun yang lalu, jauh sebelum lahirnya hukum negara yang formalitas seperti sekarang yang kemudian disebut hukum modern. $^{11}$

Penyelesaian di luar sistem baik dilakukan oleh para pihak (pelaku dan korban mandiri) ataupun dengan melibatkan penegak hukum. Ketidakpuasan terhadap Sistem Peradilan Pidana dengan demikian terkait tidak saja dengan mekanisme penanganan

10 Hadi Supeno, Kriminalisasi Anak, Tawaran Gagasan Radikal Peradilan Anak Tanpa Pemidanaan, Jakarta: Gramedia, 2010, h. 196.

${ }^{11}$ Hadi Supeno, Kriminalisasi... h. 196 
perkara dan adminstrasi, tetapi juga Hasil akhir dari proses yang berjalan. Oleh karena itu dibutuhkan suatu acara dan prosedur di dalam sistem yang dapat mengakomodasi penyelesaian perkara yang salah satunya adalah dengan menggunakan pendekatan Restorative Justice (Keadilan Restoratif), melalui suatu pembaharuan hukum yang tidak sekedar mengubah Undang-Undang semata tetapi juga memodfikasi Sistem Peradilan Pidana yang ada, sehingga semua tujuan yang di kehendaki oleh hukum pun tercapai.

\section{Restorative Justice (Keadilan}

Restoratif) meliputi pemulihan hubungan antara pihak korban dan pelaku. Pemulihan hubungan ini bisa didasarkan atas kesepakatan bersama antara korban dan pelaku. Pihak korban dapat menyampaikan mengenai kerugian yang dideritanya dan pelaku pun diberi kesempatan untuk menebusnya, melalui mekanisme ganti rugi, perdamaian, kerja sosial, maupun kesepakatan-kesepakatan lainnya. Seorang ahli Krimonologi berkebangsaan Inggris Tony F. Marshall dalam tulisannya

12 Marlina, Peradilan Pidana Anak di Indonesia, Pengembangan Konsep Diversi dan Restorative Justice, Bandung: Refika Editama, 2009, h. 88 .
"Restorative Justice an Overview" mengatakan: ${ }^{12}$

"Restorative Justice is a process whereby all the parties with a stake in aparticular offence come together to resolve collectively how to deal with theaftermath of the offence and its implication for the future" (Restorative Justice (Keadilan Restoratif) adalah sebuah proses dimana para pihak yang berkepentingan dalam pelanggaran tertentu bertemu bersama untuk menyelesaikan persoalan secara bersama-sama bagaimana menyelesaikan akibat dari pelanggaran tersebut demi kepentingan masa depan)".

Liebmann secara sederhana mengartikan Restorative Justice (Keadilan Restoratif) sebagai suatu sistem hukum yang "bertujuan untuk mengembalikan kesejahteraan korban, pelaku dan masyarakat yang rusak oleh kejahatan, dan untuk mencegah pelanggaran atau tindakan kejahatan lebih lanjut. ${ }^{13}$ Liebmann juga memberikan rumusan prinsip Restorative Justice (Keadilan Restoratif) sebagai berikut:

a. Memprioritaskan dukungan dan penyembuhan korban;

b. Pelaku pelanggaran bertanggung jawab atas apa yang mereka lakukan;

c. Dialog antara korban dengan pelaku untuk mencapai pemahaman;

13 Marian Liebmann, Restorative Justice, How it Work, London and Philadelphia: Jessica Kingsley Publishers, 2007, h. 25. 
AL-IMARAH: Jurnal Pemerintahan dan Politik Islam Vol. 5, No. 2, 2020

d. Ada upaya untuk meletakkan secara benar kerugian yang ditimbulkan;

e. Pelaku pelanggar harus sadar tentang bagaimana cara menghindari kejahatan di masa depan;

f. Masyarakat turut membantu dalam mengintegrasikan dua belah pihak, baik korban maupun pelaku. ${ }^{14}$

Hal ini dilakukan dengan mempertemukan kedua belah pihak baik pelaku maupun korban untuk memutuskan cara yang terbaik dalam menyelesaikan kasus yang ada.

Restorative Justice (Keadilan Restoratif) menurut Angkasa, Saryono Hanadi, dan Muhammad Budi Setyadi dalam ilmu hukum pidana harus bertujuan untuk memulihkan kembali keadaan seperti sebelum terjadi kejahatan. Ketika ada orang yang melakukan pelanggaran hukum maka keadaan akan menjadi berubah. Maka disitulah peran hukum untuk melindungi hakhak setiap korban kejahatan. Di dalam proses peradilan pidana konvensional dikenal adanya restitusi atau ganti rugi terhadap korban, sedangkan restorasi memiliki makna yang lebih luas. Restorasi meliputi pemulihan hubungan antara pihak korban dan pelaku. Pemulihan hubungan ini bisa didasarkan atas kesepakatan bersama antara korban dan pelaku. Pihak korban dapat menyampaikan mengenai kerugian yang dideritanya dan pelaku pun diberi kesempatan untuk menebusnya, melalui mekanisme ganti rugi,

\footnotetext{
${ }^{14}$ Marian Liebmann, Restorative ...h. 26

15 Angkasa, Saryono Hanadi, dan Muhammad Budi Setyadi, Model Peradilan Restoratif dalam Sistem Peradilan Anak (Kajian tentang Praktik Mediasi Pelaku dan Korban dalam Proses Peradilan
}

perdamaian, kerja sosial, maupun kesepakatan-kesepakatan lainnya. ${ }^{15}$

Banyak terminologi yang digunakan untuk menggambarkan konsep Restorative Justice (Keadilan Restoratif), seperti Communitarian Justice (Keadilan Komunitarian), Positive Justice (Keadilan Positif), Relational Justice (Keadilan Relasional), Reparative Justice (Keadilan Reparatif), dan Community Justice (Keadilan Masyarakat).

Gerakan Restorative Justice (Keadilan Restoratif) awalnya dimulai sebagai upaya untuk memikirkan kembali kebutuhan yang tidak terpenuhi dala $\mathrm{m}$ proses peradilan biasa. Restorative Justice memperluas lingkaran pemangku kepentingan atau pihak - pihak yang yang terlibat peristiwa atau kasus dimana bukan hanya sekedar Pemerintah dan Pelaku namun juga termasuk korban dan anggota masyarakat. ${ }^{16}$

\section{Susan Sharpe dalam bukunya "Restorative Justice a Vision for Hearing and}

Anak di Wilayah Hukum Balai Pemasyarakatan Purwokerto), 2012, h. 8.

${ }^{16}$ Howard Zehr \& Ali Gohar, The Little Book of Restorative Justice, Pennyslvania: Good Books, 2003, h. 17. 
Change" mengemukakan ada 5 (lima) prinsip dalam Restorative Justice, yaitu: ${ }^{17}$
a. Restorative Justice mangandung partisipasi penuh dan konsensus;
b. Restorative Justice berusaha menyembuhkan kerusakan atau kerugian yang ada akibat terjadinya tidak kejahatan;
c. Restorative Justice memberikan pertanggungjawaban langsung dari pelaku secara utuh;

d. Restorative Justice mencarikan penyatuan kembali kepada warga masyarakat yang terpecah atau terpisah karena tindakan kriminal;

e. Restorative Justice memberikan ketahanan kepada warga masyarakat agar dapat mencegah terjadinya tindakan kriminal berikutnya.

\section{Pentingnya Konsep Restorative Justice} (Keadilan Restorasi) Dalam R-Kuhp Mendatang (Ius Constituendum)

Kejahatan mendatangkan kerusakan dalam kehidupan masyarakat, tetapi kejahatan bisa menjadi pembelajaran bagi masyarakat untuk membuka keadilan yang sebenarnya bagi semua masyarakat. Hal ini karena faktor korelatif kriminogen lebih cenderung berakar dari persoalan yang ada di dalam masyarakat itu sendiri, seperti faktor ekonomi, sosial budaya dan bukan bersumber pada diri pelaku. Oleh karena itu korban dan pelaku harus kembali ditempatkan untuk menjaga keutuhan masyarakat dan

\footnotetext{
17 Mahmul Siregar, Pedoman Praktis Melindungi Anak dengan Hukum Pada Situasi

diposisikan sesuai dengan fungsinya dalam kehidupan bermasyarakat. Fiat Justisia Ruat Coelum, pepatah latin ini memiliki arti "meski langit runtuh keadilan dan hukum harus ditegakkan". Pepatah ini kemudian menjadi sangat populer karena sering digunakan sebagai dasar argumen pembenaran dalam pelaksanaan sebuah sistem peraturan hukum. Dalam penerapannya, adagium tersebut seolah-olah diimplementasikan dalam sebuah kerangka pemikiran yang sempit bertopeng dalih penegakan dan kepastian hukum.

Kedepan dalam rangka mencapai tujuan hukum akan disusun Rancangan KUHP yang merupakan hasil dari pemikiran bangsa Indonesia. Penyusunan Rancangan KUHP kedepan diharapkan menyasar pada 4 (empat) hal, yaitu:

a. Pencegahan dan penanggulangan kejahatan;

b. Perbaikan pada pelaku;

c. Pencegahan terhadap tindakan sewenangwenang di luar hukum; dan;

d. Penyelesaian konflik dalam masyarakat.

Keempat tolok ukur ini diletakkan dalam kerangka perlindungan masyarakat yang dicapai melalui tujuan pemidanaan. Dengan demikian, seharusnya materi Rancangan KUHP berdampak terhadap

Emergensi dan Bencana Alam, Pusat kajian dan Perlindungan Anak (PKPA), Jakarta, 2007, h. 89. 
AL-IMARAH: Jurnal Pemerintahan dan Politik Islam Vol. 5, No. 2, 2020

perubahan-perubahan substansial terkait perlindungan masyarakat yang menggeser paradigma hukum pidana nasional. Perubahan ini dipastikan akan berdampak pada banyak aspek, salah satu yang terutama adalah terhadap kondisi dan kebijakan pemasyarakatan. Dengan perubahan baik secara paradigmatik maupun materi per materi, maka proyeksi akan situasi dan kebijakan pemasyarakatan akan juga berubah seiring dengan pembaruan ini. Pembaruan terhadap Rancangan KUHP bertitik tolak pada tujuan "perlindungan masyarakat" (social defence) dan "kesejahteraan masyarakat" (social welfare). ${ }^{18}$

Kita ambil contoh mengenai upaya penyelesaian masalah di luar Pengadilan yang dilakukan oleh pelaku tindak pidana (keluarganya) dan korban tindak pidana (keluarganya) nantinya diharapkan menjadi dasar pertimbangan dalam proses pemeriksaan pelaku tindak pidana di Pengadilan dalam penjatuhan sanksi pidananya oleh hakim/majelis hakim. Restorative Justice (Keadilan Restoratif) menjadi pertimbangan dalam sistem pelaksanaan hukum pidana dan dimasukkan ke dalam Peraturan PerUndang-Undangan

18 Muladi dan Diah Sulistyani, Pertanggungjawaban Pidana Korporasi, PT Alumni, Bandung, 2013. h. 3.

${ }^{19}$ Septa Chandra, Restorative Justice: suatu tinjauan terhadap pembaharuan hukum pidana di Indonesia, 2013, h. 264. 
memikirkan kembali kebutuhan yang tidak terpenuhi dalam proses peradilan biasa. Restorative Justice (Keadilan Restoratif) memperluas lingkaran pemangku kepentingan atau pihak - pihak yang yang terlibat peristiwa atau kasus dimana bukan hanya sekedar Pemerintah dan Pelaku namun juga termasuk korban dan anggota masyarakat.

Sebenranya banyak Hukum Adat (Tranditional Law) di Indonesia yang bisa menjadi Restorative Justice (Keadilan Restoratif) sebagai salah usaha untuk mencari penyelesaian konflik secara damai di luar pengadilan atau win win solution walau pada kenyataannya masih sangat sulit diterapkan karena keberadaannya tidak diakui negara atau tidak dikodifikasikan dalam hukum nasional. ${ }^{20}$ Munculnya ide Restorative Justice (Keadilan Restoratif) sebagai kritik atas penerapan sistem peradilan pidana dengan pemenjaraan yang dianggap tidak efektif menyelesaikan konflik sosial. Penyebabnya, pihak yang terlibat dalam konflik tersebut tidak dilibatkan dalam penyelesaian konflik. Korban tetap saja menjadi korban, pelaku yang dipenjara juga

20 Eva Achjani Zulfa, Keadilan Restoratif Dan Revitalisasi Lembaga Adat Di Indonesia, Jurnal Kriminologi Indonesia Volume. 6, No. II, 2010, h. 187. memunculkan persoalan baru bagi keluarga dan sebagainya. ${ }^{21}$

Salah satu bentuk mekanisme Restoratif Justice (Keadilan Restoratif) yang bisa diterapkan dan sesuai dengan nilai-nilai budaya bangsa Indonesia adalah menggunakan teknik dialog secara kekeluargaan yang dikalangan masyarakat Indonesia lebih dikenal dengan sebutan "musyawarah untuk mufakat". Konsep Restoratif Justice (Keadilan Restoratif) ini menganggap pelaku dan korban sama-sama mendapatkan manfaat yang sebaik-baiknya sehingga dapat mengurangi angka residivis dikalangan pelaku tindak pidana serta memberikan rasa tanggung jawab bagi masing-masing pihak.

Masalah pokok
Restorative Justice sendiri, faktor penegak hukum yakni pihakpihak yang membentuk maupun menerapkan hukum, faktor sarana prasarana pendukung penegakan hukum, faktor masyarakat dimana hukum tersebut berlaku atau diterapkan, dan

${ }^{21}$ Setyo Utomo, Sistem Pemidanaan Dalam Hukum Pidana Yang Berbasis Restorative Justice, Mimbar Justitia Fakultas Hukum Universitas Suryakancana, Cianjur, Volume. V, No. 01, 2014, h. 86. 
AL-IMARAH: Jurnal Pemerintahan dan Politik Islam Vol. 5, No. 2, 2020

faktor kebudayaan yang masih menjadi kebijakan lokal masyarakat dan masih berlaku hingga kini. ${ }^{22}$

Dalam Teori Retributif, sanksi pidana bersumber pada ide "mengapa diadakan pemidanaan”. Dalam hal ini sanksi pidana lebih menekankan pada unsur pembalasan (pengimbalan) yang sesungguhnya bersifat reaktif terhadap sesuatu perbuatan. Ia merupakan penderitaan yang sengaja dibebankan kepada seorang pelanggar.

Penanggulangan kejahatan dengan menggunakan (hukum) pidana merupakan cara yang paling tua, setua peradaban manusia itu sendiri. Adapula yang menyebutnya sebagai “older philosophy of crime control". Dilihat sebagai suatu masalah kebijakan, ada yang mempermasalahkan apakah perlu kejahatan itu ditanggulangi, dicegah atau dikendalikan, dengan menggunakan sanksi pidana. ${ }^{23}$ H.L. Packer : pidana merupakan "peninggalan kebiadaban kita masa lalu" (a vestige of our savage past) yang seharusnya dihindari. ${ }^{24}$ Menurut Smith dan Hogan teori retributif tentang

${ }^{22}$ Makarao, Penerapan Restorative Justice Dalam Penyelesaian Tindak Pidana Yang Dilakukan Oleh Anak-Anak, Guru Besar Ilmu Hukum Universitas Islam As-syafi'iyah Jakarta, 2013, h. 47 - 48.

${ }^{23}$ Gene Kassebaum, Delinquency and Social Policy, London: Prentice Hall, Inc, 1974, h. 93.

pemidanaan merupakan “a relic of barbarism". ${ }^{25}$

Salah satu jenis sanksi pidana misalnya adalah pidana pencabutan kemerdekaan yang populer disebut dengan pidana penjara dan pidana kurungan. Penerapan sanksi pidana pencabutan kemerdekaan mengandung lebih banyak aspek-aspek negatif daripada aspek-aspek positifnya. Hal ini terbukti bahwa penjatuhan pidana pencabutan kemerdekaan menimbulkan hal-hal negatif sebagai berikut:

a. Dehumanisasi pelaku tindak pidana: ${ }^{26}$

1) tujuan pidana penjara pertama adalah menjamin pengamanan narapidana dan kedua adalah memberikan kesempatan kesempatan kepada narapidanauntuk direhabilitasi;

2) hakekat dari fungsi penjara tersebut di atas sering kali mengakibatkan dehumanisasi pelaku tindak pidana dan pada akhirnya menimbulkan kerugian bagi narapidana yang terlalu lama di dalam lembaga, berupa ketidak-mampuan narapidana untuk melanjutkan kehidupannya secara produktif di dalam masyarakat.

b. Prisonisasi (Prisonization) narapidana.

Proses prisonisasi narapidana dimulai ketika narapidana masuk dalam lembaga

24 H.L. Packer, The Limits of Criminal Sanction, California: Stanford Univercity Press, 1968, h. 3 .

${ }^{25}$ Smith and Hogan, Criminal Law, London: Butterworths, 1978, h. 6

${ }^{26}$ Muladi dan Barda Nawawi Arief, TeoriTeori Dan Kebijakan Pidana, Bandung: Alumni, 1984, h. 77-78. 
pemasyarakatan. Lembaga pemasyarakatan berisi kehidupan

penjara sebagai suatu sistem sosial informal yang disebut sebagai sub kultur narapidana (inmate subculture). Sub kultur narapidana ini mempunyai pengaruh besar terhadap kehidupan individual narapidana, khususnya proses sosialisasi narapidana tersebut kedalam masyarakat narapidana (the inmate community) yang oleh Clemmer disebut sebagai prisonisasi. Dalam proses prisonisasi narapidana baru (new comer) harus membiasakan diri terhadap aturanaturan yang berlaku di dalam masyarakat narapidana. Disamping itu ia harus mempelajari kepercayaan, perilakuperilaku dari masyarakat tersebut, yang akhirnya menimbulkan mental jahat. ${ }^{27}$

\section{c. A place of contamination}

Menurut Bernes dan Teeters bahwa penjara telah tumbuh menjadi tempat pencemaran (a place of contamination) yang justru harus dihindari. Di dalam penjara, penjahat kebetulan (accidental offenders), pendatang baru (novices in crime) dirusak melalui pergaulannya dengan penjahat-penjahat kronis. Bahkan personil yang paling baikpun telah gagal untuk menghilangkan keburukan yang sangat besar dari penjara ini. ${ }^{28}$

d. Pidana berjangka pendek

Pidana berjangka pendek akan sangat merugikan di dalam pembinaan sebab disamping kemungkinan hubunganhubungan yang tidak dikehendaki, pidana penjara jangka pendek jelas tidak mendukung kemungkinan untuk mengadakan rehabilitasi narapidana. ${ }^{29}$

\section{e. Stigmatization}

Kerugian lain yang sangat dirasakan dari penerapan pidana penjara adalah terjadinya stigmatisasi (stigmatization). Menurut Hoefnagels, stigma terjadi bilamana identitas seseorang terganggu atau rusak disebabkan oleh pandangan masyarakat sekitar terhadapnya. Secara psikhologis stigmatisasi menimbulkan kerugian terbesar bagi pelaku tindak pidana, karena dengan demikian publik mengetahui bahwa ia seorang penjahat, dengan segala akibatnya. ${ }^{30}$

Ada beberapa tujuan yang hendak dicapai dengan pemidanaan tersebut. G. Peter Hoefnagels, sebagaimana dikutif oleh Muladi dan Barda Nawawi Arief mengatakan bahwa tujuan pidana adalah untuk:

a. Penyelesaian konflik (conflict resolution);

b. Mempengaruhi para pelanggar dan orang-orang lain ke arah perbuatan yang kurang lebih sesuai dengan hukum (influencing offenders and possibly other than offenders toward more or less Lawconforming behavior).

Sementara Roeslan Saleh mengemukakan bahwa pada hakekatnya ada 
AL-IMARAH: Jurnal Pemerintahan dan Politik Islam Vol. 5, No. 2, 2020

dua poros yang menentukan garis-garis hukum pidana, yaitu:

a. Segi prevensi, yaitu bahwa hukum pidana adalah hukum sanksi, suatu upaya untuk dapat mempertahankan kelestarian hidup bersama dengan melakukan pencegahan kejahatan;

b. Segi pembalasan, yaitu bahwa hukum pidana sekaligus merupakan pula penentuan hukum, merupakan koreksi dari dan reaksi atas sesuatu yang bersifat tidak hukum.

Dengan demikian, pada hakekatnya pidana adalah selalu perlindungan terhadap masyarakat dan pembalasan atas perbuatan tidak hukum. Di samping itu Roeslan Saleh juga mengemukakan bahwa pidana mengandung hal-hal lain, yaitu bahwa pidana diterapkan sebagai sesuatu yang akan membawa kerukunan dan pidana adalah suatu proses pendidikan untuk menjadikan orang dapat diterima kembali dalam masyarakat.

Dari konsep normatif ditas apakah sebenarnya yang menjadi tujuan akhir (ending) dalam sebuah pemidanaan yang ada sekarang, Apakah untuk menciptakan efek jera kepada pelaku yang sudah berbuat jahat? Apakah untuk menciptakan keteraturan, ketertiban dan keamanan di dalam

masyarakat? Apakah untuk menegakan aturan hukum itu sendiri? Banyak jawabanjawaban yang ada di dalam pikiran kita maupun orang lain terkait pertanyaanpertanyaan tersebut, namun yang pasti tolak ukur keberhasilannya sebuah sistem pemidanaan ialah bukan terletak pada banyaknya jumlah tahanan maupun narapidana yang menghuni Rumah Tahanan (RUTAN) dan Lembaga Pemasyarakatan (LAPAS).

Belum lagi sistem pemidanaan yang ada sekarang seakan tidak lagi menciptakan efek jera bagi para pelaku tindak pidana atau kejahatan, malah kita dapat melihat over capacity di Rumah Tahanan (RUTAN) dan Lembaga Pemasyarakatan (LAPAS) dan berimbas pada banyaknya tindak kriminal yang terjadi di dalam lingkungan Rumah Tahanan (RUTAN) dan Lembaga Pemasyarakatan (LAPAS). Pengawasan yang lemah tidak berimbang dengan besarnya jumlah tahanan yang jumlahnya setiap hari semakin bertambah. Disudut lain Rumah Tahanan (RUTAN) dan Lembaga Pemasyarakatan (LAPAS) yang ada juga seolah tidak lagi menjadi tempat yang tepat dalam memasyarakatkan kembali para narapidana yang melakukan tindak pidana tersebut, malah seolah-olah sekarang Rumah Tahanan (RUTAN) dan Lembaga 
Pemasyarakatan (LAPAS) telah bergeser fungsinya sebagai Sekolah Kriminal (academy of crime), tempat dimana para narapidana lebih banyak belajar dan diasah kemampuannya dalam melakukan tindakan pidana. Ini jutru membuat efek yang negatif dan berdampak besar bagi tujuan pemidaan itu sendiri. Belum lagi dapat kita lihat masalah Aparat Penegak Hukum (APH) yang terlalu formalistik dan belum profesional dalam menjalankan tugas dan fungsi.

Bersamaan dengan kegagalan Sistem Peradilan Pidana yang didasari dinamika perubahan dan perkembangan hukum pidana timbul suatu paradigma penghukuman yang disebut sebagai Restorative Justice. Dalam Restorative Justice pelaku didorong untuk memperbaiki kerugian yang telah ditimbulkannya kepada korban, keluarganya dan juga masyarakat. Program utamanya adalah "a meeting place for people" guna menemukan solusi perbaikan hubungan dan kerusakan akibat kejahatan. ${ }^{31}$ Keadilan yang dilandasi perdamaian (peace) pelaku, korban dan masyarakat itulah yang menjadi moral etik Restorative Justice, oleh karena itu keadilannya dilakukan sebagai "Just Peace
Principle". Prinsip ini mengingatkan kita bahwa keadilan dan perdamaian pada dasarnya tidak dipisahkan. Perdamaian tanpa keadilan adalah penindasan, keadilan tanpa perdamaian adalah bentuk baru penganiayaan/tekanan. ${ }^{32}$ Dikatakan sebagai Just Peace Ethics karena pendekatan terhadap kejahatan dalam Restorative Justice bertujuan untuk pemulihan kerusakan akibat kejahatan (it is an attempt to recovery justice), upaya ini dilakukan dengan mempertemukan korban, pelaku dan masyarakat. ${ }^{33}$

Hambatan-hambatan yang terjadi
dalam menerapkan Restorative Justice
diantaranya adalah:

a. An identifiable victim;

b. Voluntary participation by the victim;

c. An offender who accepts responsibility for his/her criminal behaviour; and,

d. Non-coerced participation of the offender. ${ }^{34}$

Hasil yang terjadi dalam menerapkan Restorative Justice diantaranya adalah berupa: 
AL-IMARAH: Jurnal Pemerintahan dan Politik Islam Vol. 5, No. 2, 2020

a. Perdamaian dengan atau tanpa ganti Menurut Muladi, pendekatan kerugian;

keadilan restoratif menyediakan kesempatan

b. Penyerahan kembali kepada orang tua/wali;

c. Keikutsertaan dalam pendidikan atau pelatihan ke Lembaga Pendidikan, Lembaga Penyelenggaraan

Kesejahteraan Sosial atau Lembaga

Kesejahteraan Sosial; atau

d. Pelayanan Masyarakat.

Perlu adanya strategi utama untuk mengembangkan rasa tanggungjawab restoratif:

a. Fokus pada memulihkan kerugian korban;

b. Menyelenggarkan suatu proses untuk mengamankan kepentingan Masyarakat;

c. Menyelenggarakan suatu proses untuk meningkatkan pemahaman lebih luas tentang pengaruh tindak pidana terhadap orang lain dan masyarakat;

d. Menawarkan cara-cara yang berarti bagi pelaku untuk bertanggung jawab terhadap perbuatannya;

e. Menggalakkan permintaan maaf atau ekspresi penyesalan pelaku;

f. Melibatkan korban dan masyarakat dalam menentukan tindakan pertanggungjawaban. dan kemungkinan bagi korban kejahatan untuk memperoleh reparasi, rasa aman, memungkinkan pelaku untuk memahami sebab dan akibat perilakunya dan bertanggungjawab dengan cara yang berarti dan memungkinkan masyarakat untuk memahami sebab utama terjadinya kejahatan, untuk memajukan kesejahteraan masyarakat dan mencegah kejahatan. Pendekatan Keseimbangan (Balanced Approach) untuk mengantikan pendekatan punitive-retributif sangat dibutuhkan dalam sistem keadilan restoratif untuk memenuhi kepentingan pelaku atas proses rahabilitasi dan reintegrasi; kepentingan korbanakan restorasi akibat tindak pidana; dan kebutuhan masyarakat akan peningkatan keamanan dan keselamatan. Keberadaan strategi proses keadilan restoratif khusus bagi anakanak/remaja yang berimbang (The Balanced Restorative Justice for Juvenile) dilandasai oleh pemikiran bahwa sumber kejahatan dan pelanggaran anak-anak (delinquency) adalah masyarakat, keluarga, sekolah, sehingga strategi yang hanya menitikberatkan pada individual pelaku tidak tepat. Pelibatan elemen-elemen korban dan masyarakat settya professional akan menyelesaikan persoalnnya secara sistemik dan 
komprehensif. Keadilan restoratif Perwakilan Rakyat ke depannya perlu menampilkan serangkaian tindakan yang fleksibel yang dapat diesuaikan dengan Sistem Peradilan Pidana yang berlaku dan secara komplementer dilakukan dengan mempertimbangkan kondisi hukum, sosial dan budaya. Pendayagunaan keadilan restoratif tidak akan merugikan hak Negara untuk menuntut pelaku tindak pidana yang dicurigai. $^{35}$

\section{Penutup}

\section{Kesimpulan}

Dalam konteks pembaharuan hukum pidana di Indonesia lewat Rancangan Kitab Undang-Undang Hukum Pidana (RKUHP) harus mengakomodir dan memasukan prinsip Restorative Justice (Keadilan Restoratif), dimana rumusan tentang jenis-jenis pidana (strafmaat) mengandung sifat restoratif. Sehingga sangat mungkin sekali konsep Restorative Justice (Keadilan Restoratif) ini dapat dijadikan bagian dari pembaharuan hukum pidana di Indonesia di masa yang akan datang.

\section{Rekomendasi}

\section{Bagi pembentuk Undang-Undang dalam hal ini Presiden dan Dewan}


AL-IMARAH: Jurnal Pemerintahan dan Politik Islam Vol. 5, No. 2, 2020

Proses Peradilan Anak di Wilayah Hukum Balai Pemasyarakatan Purwokerto), 2012.

Daniel S. Lev, Hukum dan Politik di Indonesia: Keseimbangan dan Perubahan, Cetakan I, LP3ES, Jakarta, 1990.

Eva Achjani Zulfa, Keadilan Restoratif Dan Revitalisasi Lembaga Adat Di Indonesia, Jurnal Kriminologi Indonesia Volume. 6, No. II, 2010.

Gene Kassebaum, Delinquency and Social Policy, London: Prentice Hall, Inc, 1974.

H.L. Packer, The Limits of Criminal Sanction, California: Stanford University Press, 1968.

Hadi Supeno, Kriminalisasi Anak, Tawaran Gagasan Radikal Peradilan Anak Tanpa Pemidanaan, Jakarta: Gramedia, 2010.

Howard Zehr \& Ali Gohar, The Little Book of Restorative Justice, Pennyslvania: Good Books, 2003.

John Brithwaite, Restorative Justice and Responsive Regulation, University Press, Oxford, 2002.
Joni Emirzon, Alternatif Penyelesaian Sengketa di Luar Pengadilan, Jakarta, PT. Gramedia Pustaka Utama, 2001.

Kuat Puji Prayitno, Aplikasi Konsep Restorative Justice dalam Peradilan Indonesia, Yogyakarta: Genta Publishing, 2012.

Mahmul Siregar, Pedoman Praktis Melindungi Anak dengan Hukum Pada Situasi Emergensi dan Bencana Alam, Pusat kajian dan Perlindungan Anak (PKPA), Jakarta, 2007.

Makarao, Penerapan Restorative Justice Dalam Penyelesaian Tindak Pidana Yang Dilakukan Oleh Anak-Anak, Guru Besar Ilmu Hukum Universitas Islam As-syafi'iyah Jakarta, 2013.

Marian Liebmann, Restorative Justice, How it Work, London and Philadelphia: Jessica Kingsley Publishers, 2007. Marlina, Peradilan Pidana Anak di Indonesia, Pengembangan Konsep Diversi dan Restorative Justice, Bandung: Refika Editama, 2009. 
Muladi dan Barda Nawawi Arief, Teori-Teori Dan Kebijakan Pidana, Bandung: Alumni, 1984.

Muladi dan Diah Sulistyani, Pertanggungjawaban Pidana Korporasi, PT Alumni, Bandung, 2013.

Muladi, Kapita Selekta Hukum Pidana, Semarang: BP Universitas Diponegoro, 1995.

Otong Rosadi dan Andi Desmon, Studi Politik Hukum: Suatu Optik Ilmu Hukum, Edisi II, Thafa media, Yogyakarta, 2013.

Romli Atmasasmita, Teori Hukum Integratif: Rekonstruksi Terhadap Teori Hukum Pembangunan dan Teori Hukum Progresif, Genta Publishing, Yogyakarta, 2012

Satjipto Rahardjo, Sisi-Sisi Lain dar ni Hukum di Indonesia, Jakarta: Kompas, 2003.

Septa Chandra, Restorative Justice: suatu tinjauan terhadap pembaharuan hukum pidana di Indonesia, 2013.

Setyo Utomo, Sistem Pemidanaan Dalam Hukum Pidana Yang Berbasis Restorative Justice, Mimbar Justitia
Fakultas Hukum Universitas Suryakancana, Cianjur, Volume. V, No. 01, 2014.

Smith and Hogan, Criminal Law, London: Butterworths, 1978.

\section{Undang-Undang}

Undang-Undang Nomor 25 Tahun 2004 Tentang Sistem Perencanaan Pembangunan Nasional. 